CRYSTALLOGRAPHIC COMMUNICATIONS

ISSN 2056-9890

\section{Crystal structure, Hirshfeld surface analysis and interaction energy and DFT studies of 5,5-diphenyl- 1,3-bis(prop-2-yn-1-yl)imidazolidine-2,4-dione}

\author{
Ismail Ghandour, ${ }^{a}$ Abdelouahed Bouayad, ${ }^{\text {a }}$ Tuncer Hökelek, ${ }^{\text {b }}$ Amal Haoudi, ${ }^{\text {c* }}$ \\ Frédéric Capet, ${ }^{d}$ Catherine Renard ${ }^{d}$ and Youssef Kandri Rodi ${ }^{\mathrm{C}}$
}

Received 15 May 2019

Accepted 30 May 2019

Edited by A. J. Lough, University of Toronto, Canada

Keywords: crystal structure; imidazolidine; oxazole; $\pi$-stacking; Hirshfeld surface.

CCDC reference: 1919743

Supporting information: this article has supporting information at journals.iucr.org/e

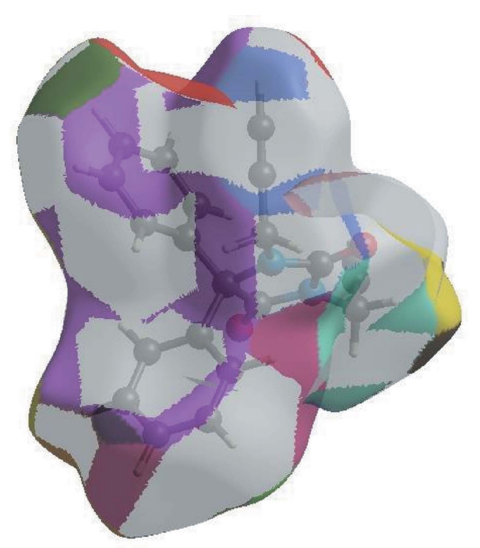

OPEN $\odot$ ACCESS
aLaboratoire de Chimie de la Matière Condensée, Université Sidi Mohamed Ben Abdallah, Faculté des Sciences et Techniques, Route d'Immouzzer, BP 2202, Fez, Morocco, 'b Department of Physics, Hacettepe University, 06800 Beytepe, Ankara, Turkey, 'Laboratoire de Chimie Organique Appliquée, Université Sidi Mohamed Ben Abdallah, Faculté des Sciences et Techniques, Route d'Immouzzer, BP 2202, Fez, Morocco, and 'dUnité de Catalyse et de Chimie du Solide (UCCS), UMR 8181, Ecole Nationale Supérieure de Chimie de Lille, Université Lille 1, 59650 Villeneuve, d'Ascq, Cedex, France. *Correspondence e-mail: amalhaoudi2017@gmail.com

The title compound, $\mathrm{C}_{21} \mathrm{H}_{16} \mathrm{~N}_{2} \mathrm{O}_{2}$, consists of an imidazolidine unit linked to two phenyl rings and two prop-2-yn-1-yl moieties. The imidazolidine ring is oriented at dihedral angles of $79.10(5)$ and $82.61(5)^{\circ}$ with respect to the phenyl rings, while the dihedral angle between the two phenyl rings is $62.06(5)^{\circ}$. In the crystal, intermolecular $\mathrm{C}-\mathrm{H}_{\text {Prop }} \cdots \mathrm{O}_{\text {Imdzln }}$ (Prop = prop-2-yn-1-yl and Imdzln = imidazolidine) hydrogen bonds link the molecules into infinite chains along the $b$-axis direction. Two weak $\mathrm{C}-\mathrm{H}_{\mathrm{Phen}} \cdots \pi$ interactions are also observed. The Hirshfeld surface analysis of the crystal structure indicates that the most important contributions for the crystal packing are from $\mathrm{H} \cdots \mathrm{H}(43.3 \%), \mathrm{H} \cdots \mathrm{C} /$ $\mathrm{C} \cdots \mathrm{H}(37.8 \%)$ and $\mathrm{H} \cdots \mathrm{O} / \mathrm{O} \cdots \mathrm{H}(18.0 \%)$ interactions. Hydrogen bonding and van der Waals interactions are the dominant interactions in the crystal packing. Computational chemistry indicates that the $\mathrm{C}-\mathrm{H}_{\text {Prop }} \cdots \mathrm{O}_{\text {Imdzln }}$ hydrogen-bond energy in the crystal is $-40.7 \mathrm{~kJ} \mathrm{~mol}^{-1}$. Density functional theory (DFT) optimized structures at the B3LYP/6-311G(d,p) level are compared with the experimentally determined molecular structure in the solid state. The HOMOLUMO behaviour was elucidated to determine the energy gap.

Pyrazolones are an important class of heterocyclic compounds that occur in many drugs and their derivatives have long been of interest to medicinal chemists for their wide range of biological activities (Pawar \& Patil, 1994), including antibacterial, antidiabetic, immunosuppressive agents, and substances displaying hypoglycemic, antiviral and antineoplastic actions (Pathak \& Bahel, 1980; Naik \& Malik, 2010; Srivalli et al., 2011). Their pharmaceutical applications include use as a non-steroidal anti-inflammatory agent in the treatment of arthritis and other musculoskeletal and joint disorders (Amir \& Kumar, 2005), and as analgesic, antipyretic (Badawey \& El-Ashmawey, 1998) and hypoglycemic agents (Das et al., 2008). They also have fungicidal (Singh \& Singh, 1991) and antimicrobial properties (Sahu et al., 2007), and some have 2006). In the past few years, research has been focused on existing molecules and their modifications in order to reduce side effects and to explore other pharmacological and biological activity (Sahu et al., 2007; Naik \& Malik, 2010; Srivalli et al., 2011). As a continuation of our research on the development of new $\mathrm{N}$-substituted pyrazolone derivatives and the

\section{Chemical context} been tested as potential cardiovascular drugs (Higashi et al., 
evaluation of their potential pharmacological activities, we report herein the synthesis, the molecular and crystal structures, the Hirshfeld surface analysis and intermolecular interaction energies and density functional theory (DFT) computational calculation of the title compound, (I).

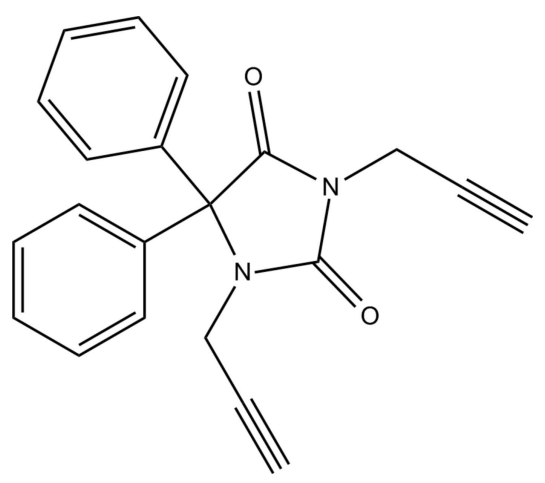

\section{Structural commentary}

The title molecule consists of an imidazolidine unit linked to two phenyl rings and two prop-2-yn-1-yl moieties (Fig. 1). The planar five-membered imidazolidine ring, $A(\mathrm{~N} 1 / \mathrm{N} 2 / \mathrm{C} 1-\mathrm{C} 3)$, is oriented at dihedral angles of $79.10(5)$ and $82.61(5)^{\circ}$, respectively, to phenyl rings $B$ (C4-C9) and $C(\mathrm{C} 10-\mathrm{C} 15)$, while the dihedral angle between the two phenyl rings is $62.06(5)^{\circ}$. Atoms O1, O2, C16 and $\mathrm{C} 19$ are at distances of 0.0271 (12), -0.1040 (12), 0.1657 (19) and -0.0336 (19) ^ from the mean plane of the imidazolidine ring, $A$. The orientation of the prop-2-yn-1-yl moieties with respect to the imidazolidine unit can be described by the $\mathrm{C} 3-\mathrm{N} 1-\mathrm{C} 16-$ $\mathrm{C} 17$ and $\mathrm{C} 3-\mathrm{N} 2-\mathrm{C} 19-\mathrm{C} 20$ torsion angles of -115.3 (2) and $76.6(2)^{\circ}$, respectively.

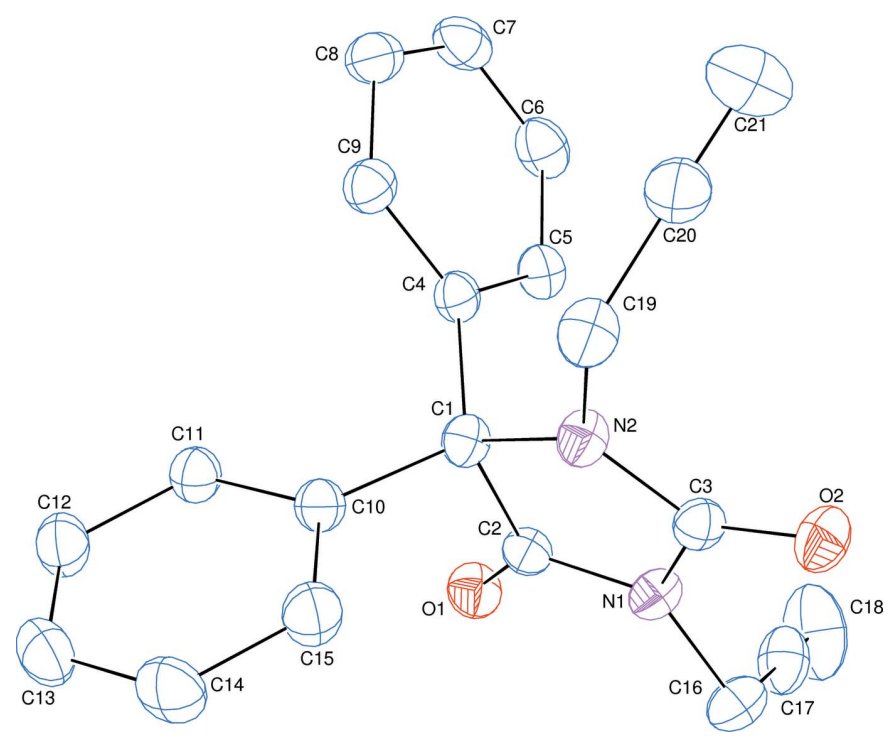

Figure 1

The molecular structure of the title compound with the atom-numbering scheme. Displacement ellipsoids are drawn at the $50 \%$ probability level.
Table 1

Hydrogen-bond geometry $\left(\AA,^{\circ}\right)$.

$C g 1$ and $C g 2$ are the centroids of the $\mathrm{C} 4-\mathrm{C} 9$ and $\mathrm{C} 10-\mathrm{C} 15$ rings, respectively.

\begin{tabular}{|c|c|c|c|c|}
\hline$D-\mathrm{H} \cdots A$ & $D-\mathrm{H}$ & $\mathrm{H} \cdots A$ & $D \cdots A$ & $D-\mathrm{H} \cdots A$ \\
\hline $\mathrm{C} 16-\mathrm{H} 16 B \cdots \mathrm{O} 2^{\text {vii }}$ & $0.98(3)$ & $2.33(3)$ & $3.178(3)$ & $144(2)$ \\
\hline $\mathrm{C} 9-\mathrm{H} 9 \cdots C g 1^{\mathrm{vi}}$ & $0.93(3)$ & $2.93(2)$ & $3.778(2)$ & $152.7(17)$ \\
\hline $\mathrm{C} 14-\mathrm{H} 14 \cdots C g 2^{\mathrm{viii}}$ & $1.00(3)$ & $2.87(2)$ & $3.762(3)$ & $149.6(17)$ \\
\hline
\end{tabular}

\section{Supramolecular features}

In the crystal, $\mathrm{C}-\mathrm{H}_{\text {Prop }} \cdots \mathrm{O}_{\text {Imdzln }}$ (Prop = prop-2-yn-1-yl and Imdzln = imidazolidine) hydrogen bonds (Table 1 and Fig. 2) link the molecules into infinite chains along the $b$-axis direction. Two weak $\mathrm{C}-\mathrm{H}_{\mathrm{Phen}} \cdots \pi$ interactions (Table 1 ) may also contribute to the stabilization of the crystal structure.

\section{Hirshfeld surface analysis}

In order to visualize the intermolecular interactions in the crystal of the title compound, a Hirshfeld surface (HS) analysis (Hirshfeld, 1977; Spackman \& Jayatilaka, 2009) was carried out by using CrystalExplorer17.5 (Turner et al., 2017). In the HS plotted over $d_{\text {norm }}$ (Fig. 3), the white surface indicates contacts with distances equal to the sum of van der Waals radii, and the red and blue colours indicate distances shorter (in close contact) or longer (distinct contact) than the van der Waals radii, respectively (Venkatesan et al., 2016). The brightred spots appearing near $\mathrm{O} 2$ and hydrogen atom $\mathrm{H} 16 B$ indicate their roles as the respective donors and/or acceptors; they also appear as blue and red regions corresponding to positive and negative potentials on the HS mapped over electrostatic potential (Spackman et al., 2008; Jayatilaka et al., 2005) as shown in Fig. 4. The blue regions indicate the positive electrostatic potential (hydrogen-bond donors), while the red regions indicate the negative electrostatic potential

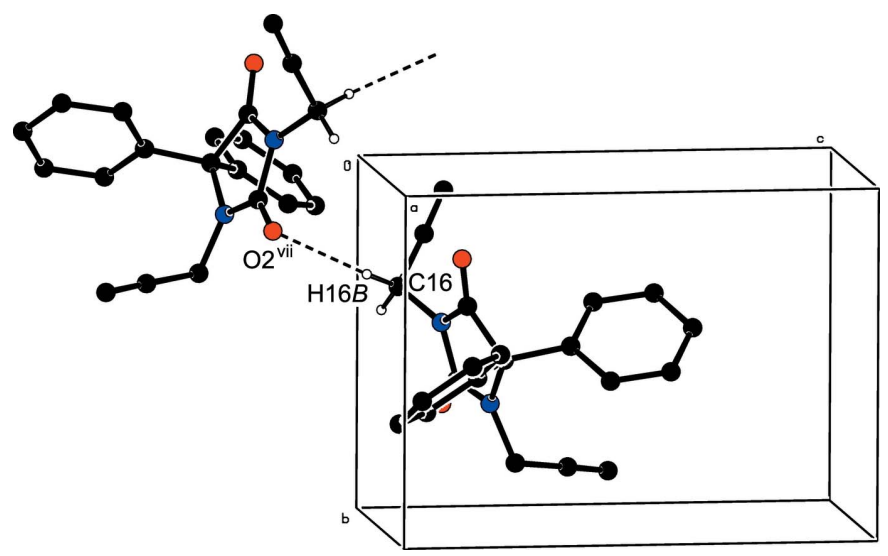

Figure 2

A partial packing diagram viewed down the $a$-axis direction. C$\mathrm{H}_{\text {Prop }} \cdots \mathrm{N}_{\text {Imdzln }}$ (Prop = prop-2-yn-1-yl and Imdzln = imidazolidine) hydrogen bonds (Table 1) are shown as dashed lines. Symmetry code: (vii) $-x, y-\frac{1}{2},-z$. 


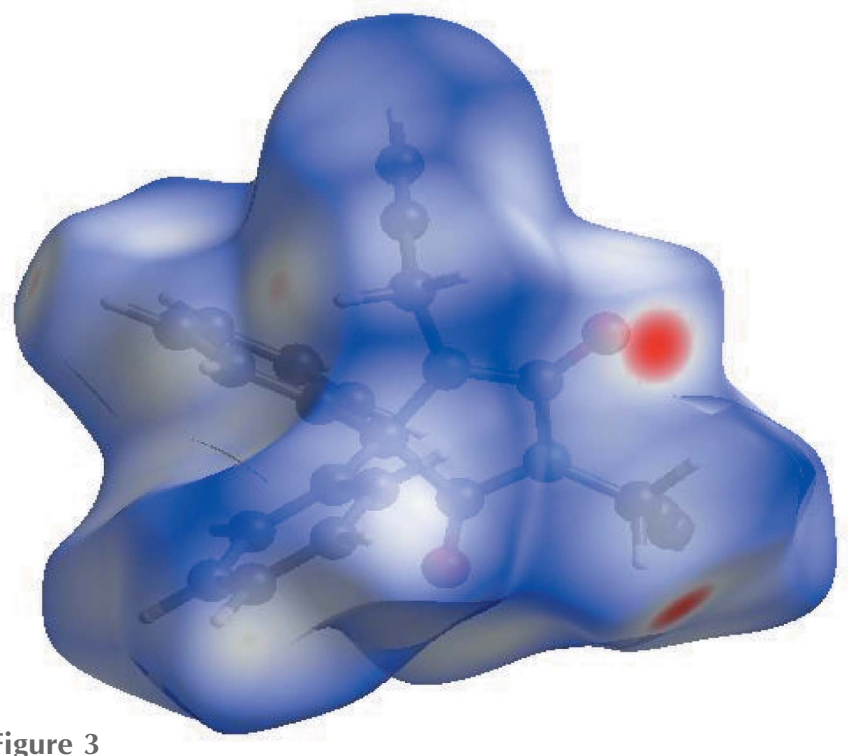

Figure 3

View of the three-dimensional Hirshfeld surface of the title compound plotted over $d_{\text {norm }}$ in the range -0.2703 to 1.2169 a.u.

(hydrogen-bond acceptors). The shape-index of the HS is a tool to visualize the $\pi-\pi$ stacking by the presence of adjacent red and blue triangles; if there are no adjacent red and/or blue triangles, then there are no $\pi-\cdot \pi$ interactions. Fig. 5 clearly suggest that there are no $\pi-\pi$ interactions in (I).

The overall two-dimensional fingerprint plot, Fig. $6 a$, and those delineated into $\mathrm{H} \cdots \mathrm{H}, \mathrm{H} \cdots \mathrm{C} / \mathrm{C} \cdots \mathrm{H}, \mathrm{H} \cdots \mathrm{O} / \mathrm{O} \cdots \mathrm{H}$,

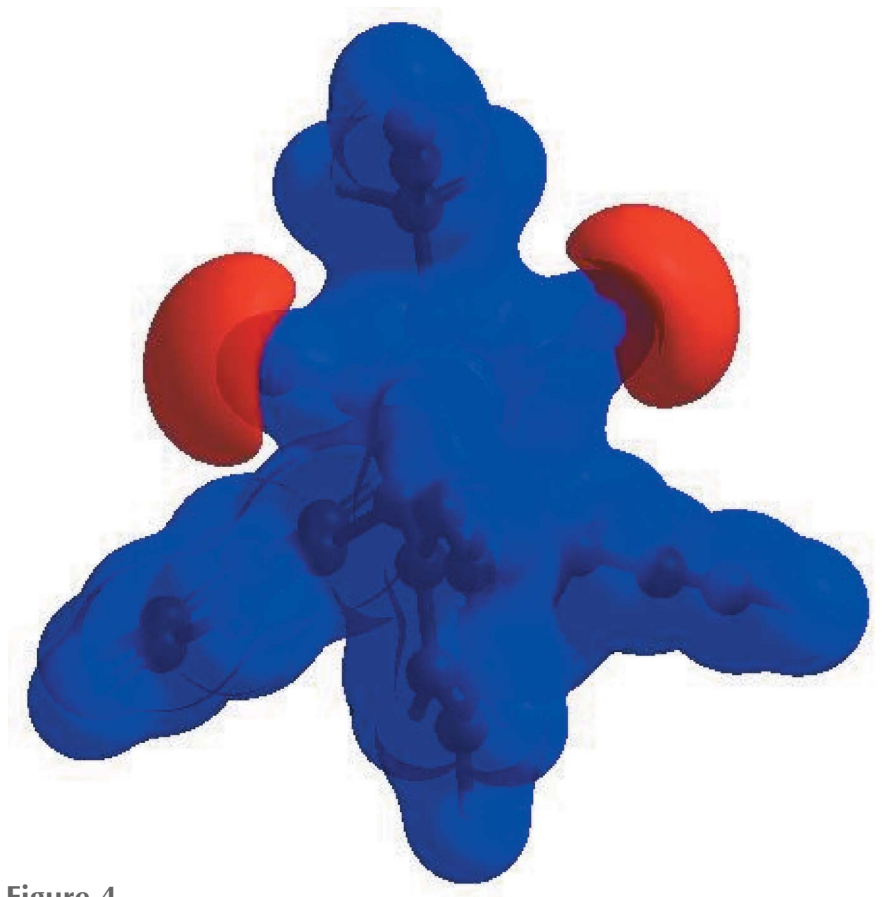

Figure 4

View of the three-dimensional Hirshfeld surface of the title compound plotted over electrostatic potential energy in the range -0.0500 to 0.0500 a.u. using the STO-3 G basis set at the Hartree-Fock level of theory. Hydrogen-bond donors and acceptors are shown as blue and red regions around the atoms corresponding to positive and negative potentials, respectively.
Table 2

Selected interatomic distances $(\AA)$.

\begin{tabular}{llll}
\hline $\mathrm{O} 1 \cdots \mathrm{H} 16 B$ & $2.84(2)$ & $\mathrm{C} 4 \cdots \mathrm{H} 11$ & $2.679(18)$ \\
$\mathrm{O} 1 \cdots \mathrm{H} 13^{\mathrm{i}}$ & $2.61(2)$ & $\mathrm{C} 6 \cdots \mathrm{H} 9^{\mathrm{ii}}$ & $2.97(2)$ \\
$\mathrm{O} 1 \cdots \mathrm{H} 5$ & $2.767(18)$ & $\mathrm{C} 6 \cdots \mathrm{H} 18^{\mathrm{v}}$ & $2.90(4)$ \\
$\mathrm{O} 1 \cdots \mathrm{H} 8^{\mathrm{ii}}$ & $2.62(2)$ & $\mathrm{C} 8 \cdots \mathrm{H} 11^{\mathrm{vi}}$ & $2.94(2)$ \\
$\mathrm{O} 2 \cdots \mathrm{H} 18^{\mathrm{iii}}$ & $2.68(5)$ & $\mathrm{C} 8 \cdots \mathrm{H} 19 A^{\mathrm{ii}}$ & $2.83(2)$ \\
$\mathrm{O} 2 \cdots \mathrm{H} 19 B$ & $2.65(2)$ & $\mathrm{C} 9 \cdots \mathrm{H} 11$ & $2.73(2)$ \\
$\mathrm{O} 2 \cdots \mathrm{H} 16 A$ & $2.50(2)$ & $\mathrm{C} 10 \cdots \mathrm{H} 9$ & $2.75(2)$ \\
$\mathrm{O} 2 \cdots \mathrm{H} 16 B^{\text {iv }}$ & $2.33(2)$ & $\mathrm{C} 10 \cdots \mathrm{H} 19 A$ & $2.96(2)$ \\
$\mathrm{N} 2 \cdots \mathrm{H} 15$ & $2.53(2)$ & $\mathrm{C} 11 \cdots \mathrm{H} 14^{\mathrm{i}}$ & $2.94(2)$ \\
$\mathrm{C} 4 \cdots \mathrm{C} 20$ & $3.372(3)$ & $\mathrm{C} 11 \cdots \mathrm{H} 9$ & $2.79(2)$ \\
$\mathrm{C} 9 \cdots \mathrm{C} 19$ & $3.378(3)$ & $\mathrm{C} 12 \cdots \mathrm{H} 14^{\mathrm{i}}$ & $2.91(2)$ \\
$\mathrm{C} 9 \cdots \mathrm{C} 11$ & $3.138(3)$ & $\mathrm{C} 14 \cdots \mathrm{H} 7^{\mathrm{vi}}$ & $2.97(2)$ \\
$\mathrm{C} 9 \cdots \mathrm{C} 20$ & $3.472(3)$ & $\mathrm{H} 8 \cdots \mathrm{H} 11^{\mathrm{vi}}$ & $2.53(3)$ \\
$\mathrm{C} 15 \cdots \mathrm{C} 19$ & $3.450(3)$ & $\mathrm{H} 9 \cdots \mathrm{H} 11$ & $2.58(3)$ \\
$\mathrm{C} 2 \cdots \mathrm{H} 5$ & $2.476(18)$ & & \\
\hline
\end{tabular}

Symmetry codes: (i) $-x+1, y-\frac{1}{2},-z$; (ii) $-x+1, y-\frac{1}{2},-z+1$; (iii) $x, y+1, z$; (iv) $-x, y+\frac{1}{2},-z ;(\mathrm{v})-x, y+\frac{1}{2},-z+1$; (vi) $-x+1, y+\frac{1}{2},-z+1$.

C. . C and H. N/N ..H contacts (McKinnon et al., 2007) are illustrated in Fig. $6 b-f$, together with their relative contributions to the Hirshfeld surface while details of the various contacts are given in Table 2. The most important interaction is $\mathrm{H} \cdots \mathrm{H}$ contributing $43.3 \%$ to the overall crystal packing, which is reflected in Fig. $6 b$ as widely scattered points of high density due to the large hydrogen content of the molecule with the tip at $d_{\mathrm{e}}+d_{\mathrm{i}} \sim 2.44 \AA$. In the presence of two weak $\mathrm{C}-$ $\mathrm{H} \cdots \pi$ interactions, the pair of the scattered points of wings resulting from $\mathrm{H} \cdots \mathrm{C} / \mathrm{C} \cdots \mathrm{H}$ contacts, with a $37.8 \%$ contribution to the HS, have a symmetrical distribution of points, Fig. $6 c$, with the thin edges at $d_{\mathrm{e}}+d_{\mathrm{i}}=2.67 \AA$. The fingerprint

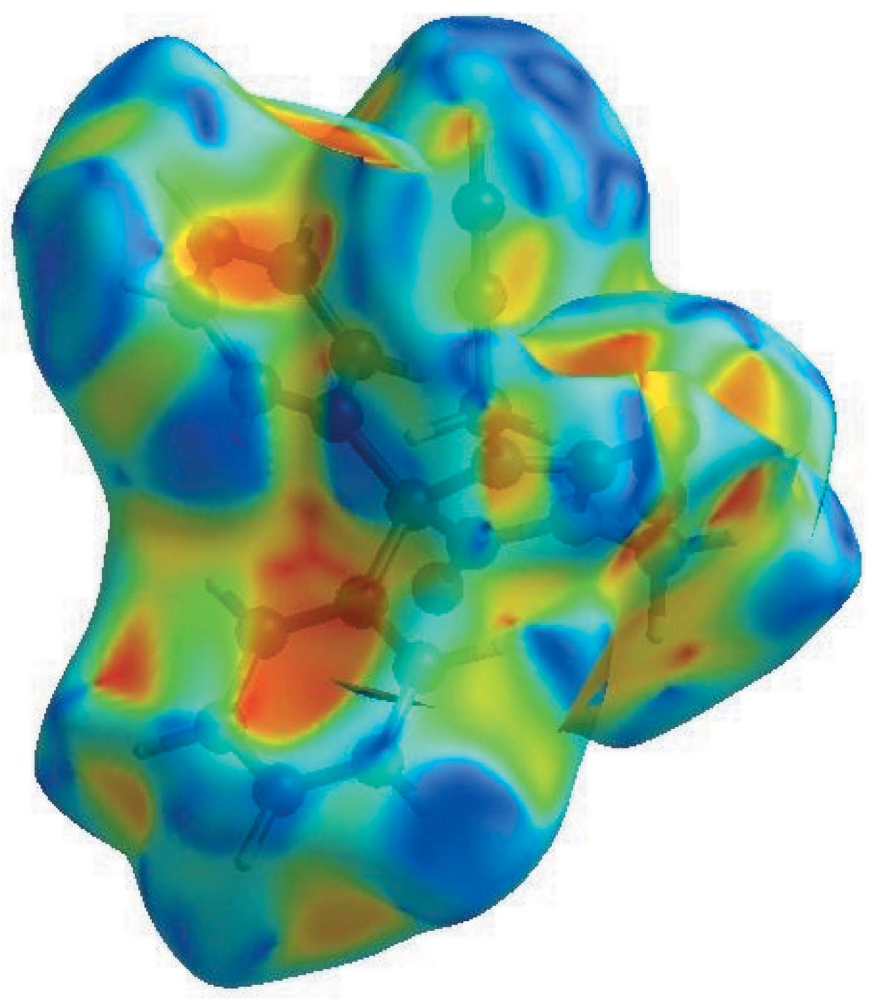

Figure 5

Hirshfeld surface of the title compound plotted over shape-index. 
plot for $\mathrm{H} \cdots \mathrm{O} / \mathrm{O} \cdots \mathrm{H}$ contacts $(18.0 \%$ contribution), Fig. $6 d$, has a pair of spikes with the tips at $d_{\mathrm{e}}+d_{\mathrm{i}}=2.24 \AA$.

The Hirshfeld surface representations with the function $d_{\text {norm }}$ plotted onto the surface are shown for the $\mathrm{H} \cdots \mathrm{H}$, $\mathrm{H} \cdots \mathrm{C} / \mathrm{C} \cdots \mathrm{H}$ and $\mathrm{H} \cdots \mathrm{O} / \mathrm{O} \cdots \mathrm{H}$ interactions in Fig. $7 a-c$.

The Hirshfeld surface analysis confirms the importance of $\mathrm{H}$-atom contacts in establishing the packing. The large number of $\mathrm{H} \cdots \mathrm{H}, \mathrm{H} \cdots \mathrm{C} / \mathrm{C} \cdots \mathrm{H}$ and $\mathrm{H} \cdots \mathrm{O} / \mathrm{O} \cdots \mathrm{H}$ interactions suggest that van der Waals interactions and hydrogen bonding play the major roles in the crystal packing (Hathwar et al., 2015).

\section{Interaction energy calculations}

The intermolecular interaction energies (Table 3) were calculated using the CE-B3LYP/6-311G(d,p) energy model available in CrystalExplorer17.5 (Turner et al., 2017), where a cluster of molecules is generated by applying crystallographic symmetry operations with respect to a selected central molecule within a default radius of $3.8 \AA$ (Turner et al., 2014). The total intermolecular energy $\left(E_{\mathrm{tot}}\right)$ is the sum of electrostatic
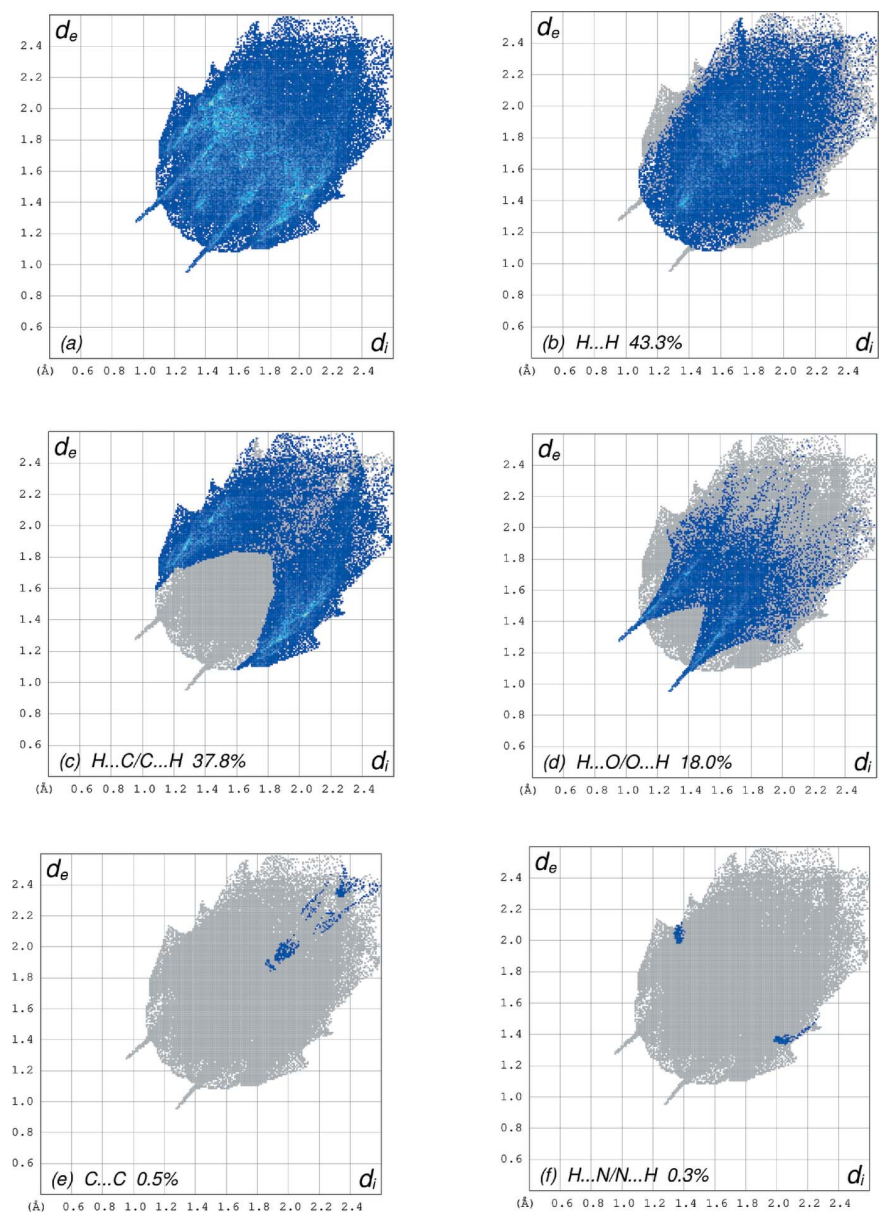

Figure 6

The full two-dimensional fingerprint plots for the title compound, showing $(a)$ all interactions, and delineated into $(b) \mathrm{H} \cdots \mathrm{H},(c) \mathrm{H} \cdots \mathrm{C} /$ $\mathrm{C} \cdots \mathrm{H},(d) \mathrm{H} \cdots \mathrm{O} / \mathrm{O} \cdots \mathrm{H},(e) \mathrm{C} \cdots \mathrm{C}$ and $(f) \mathrm{H} \cdots \mathrm{N} / \mathrm{N} \cdots \mathrm{H}$ interactions. The $d_{\mathrm{i}}$ and $d_{\mathrm{e}}$ values are the closest internal and external distances (in $\AA$ ) from given points on the Hirshfeld surface contacts.
Table 3

Calculated energies and other parameters for (I).

\begin{tabular}{lr}
\hline Parameter & Value in $(\mathrm{I})$ \\
\hline Total energy $E_{\text {tot }}(\mathrm{eV})$ & -30168.2025 \\
$E_{\text {HOMO }}(\mathrm{eV})$ & -6.6964 \\
$E_{\text {LUMO }}(\mathrm{eV})$ & -0.8090 \\
Energy gap, $\Delta E(\mathrm{eV})$ & 5.8878 \\
Dipole moment, $\mu(\mathrm{Debye})$ & 2.5919 \\
Ionization potential, $I(\mathrm{eV})$ & 6.6964 \\
Electron affinity, $A$ & 0.8090 \\
Electro negativity, $\chi$ & 4.0554 \\
Hardness, $\eta$ & 2.9437 \\
Electrophilicity index, $\omega$ & 2.3920 \\
Softness, $\sigma$ & 0.3397 \\
Fraction of electrons transferred, $\Delta N$ & 0.5516 \\
\end{tabular}

$\left(E_{\text {ele }}\right)$, polarization $\left(E_{\mathrm{pol}}\right)$, dispersion $\left(E_{\mathrm{dis}}\right)$ and exchangerepulsion $\left(E_{\text {rep }}\right)$ energies (Turner et al., 2015) with scale factors of 1.057, 0.740, 0.871 and 0.618, respectively (Mackenzie et al., 2017). The hydrogen-bonding interaction energy (in $\mathrm{kJ} \mathrm{mol}^{-1}$ ) was calculated to be $-15.3\left(E_{\text {ele }}\right),-3.2\left(E_{\mathrm{pol}}\right),-52.2\left(E_{\mathrm{dis}}\right)$, $37.6\left(E_{\text {rep }}\right)$ and $-40.7\left(E_{\text {tot }}\right)$ for the $\mathrm{C}-\mathrm{H}_{\text {Prop }} \cdots \mathrm{N}_{\text {Imdzln }}$ interaction.

\section{DFT calculations}

The optimized structure of the title compound in the gas phase was generated theoretically via density functional theory (DFT) calculations using the standard B3LYP functional and

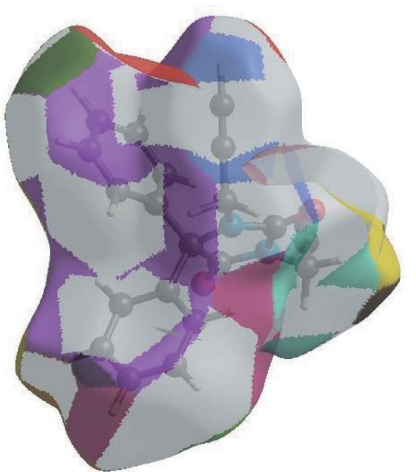

(a)

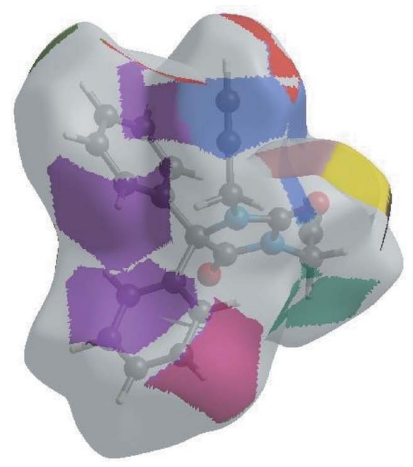

(b)

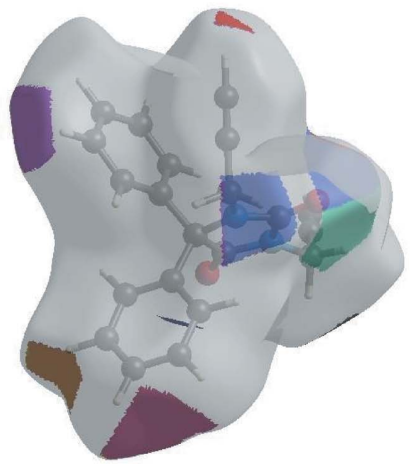

(c)

Figure 7

The Hirshfeld surface representations with the function $d_{\text {norm }}$ plotted onto the surface for $(a) \mathrm{H} \cdots \mathrm{H},(b) \mathrm{H} \cdots \mathrm{C} / \mathrm{C} \cdots \mathrm{H}$ and $\mathrm{H} \cdots \mathrm{O} / \mathrm{O} \cdots \mathrm{H}$ interactions. 
Table 4

Comparison of the selected (X-ray and DFT) geometric data $\left(\AA,^{\circ}\right)$.

\begin{tabular}{lll}
\hline Bonds/angles & X-ray & B3LYP/6-311G(d,p) \\
\hline O1-C2 & $1.203(3)$ & 1.237 \\
O2-C3 & $1.208(2)$ & 1.242 \\
N2-C3 & $1.346(3)$ & 1.379 \\
N2-C1 & $1.472(3)$ & 1.494 \\
N2-C19 & $1.454(3)$ & 1.470 \\
N1-C3 & $1.399(3)$ & 1.414 \\
N1-C2 & $1.360(3)$ & 1.384 \\
N1-C16 & $1.453(3)$ & 1.467 \\
C3-N2-C1 & $112.90(16)$ & 112.45 \\
C3-N2-C19 & $121.81(18)$ & 120.14 \\
N2-C3-N1 & $107.02(17)$ & 106.95 \\
C3-N1-C16 & $122.9(2)$ & 122.80 \\
C2-N1-C3 & $112.60(17)$ & 112.41 \\
O2-C3-N2 & $128.0(2)$ & 127.88 \\
O2-C3-N1 & $125.0(2)$ & 125.10 \\
\hline
\end{tabular}

6-311G(d,p) basis set (Becke, 1993) as implemented in GAUSSIAN 09 (Frisch et al., 2009). The theoretical and experimental results are in good agreement (Table 4). The highest occupied molecular orbital (HOMO), acting as an electron donor, and the lowest unoccupied molecular orbital (LUMO), acting as an electron acceptor, are very important parameters for quantum chemistry. When the energy gap is small, the molecule is highly polarizable and has high chemical reactivity. The DFT calculations provide some important information on the reactivity and site selectivity of the molecular framework. $E_{\mathrm{HOMO}}$ and $E_{\mathrm{LUMO}}$ clarify the inevitable charge-exchange collaboration inside the studied material; the electronegativity $(\chi)$, hardness $(\eta)$, potential $(\mu)$, electrophilicity $(\omega)$ and softness $(\sigma)$ are recorded in Table 3 . The significance of $\eta$ and $\sigma$ is to evaluate both the reactivity and

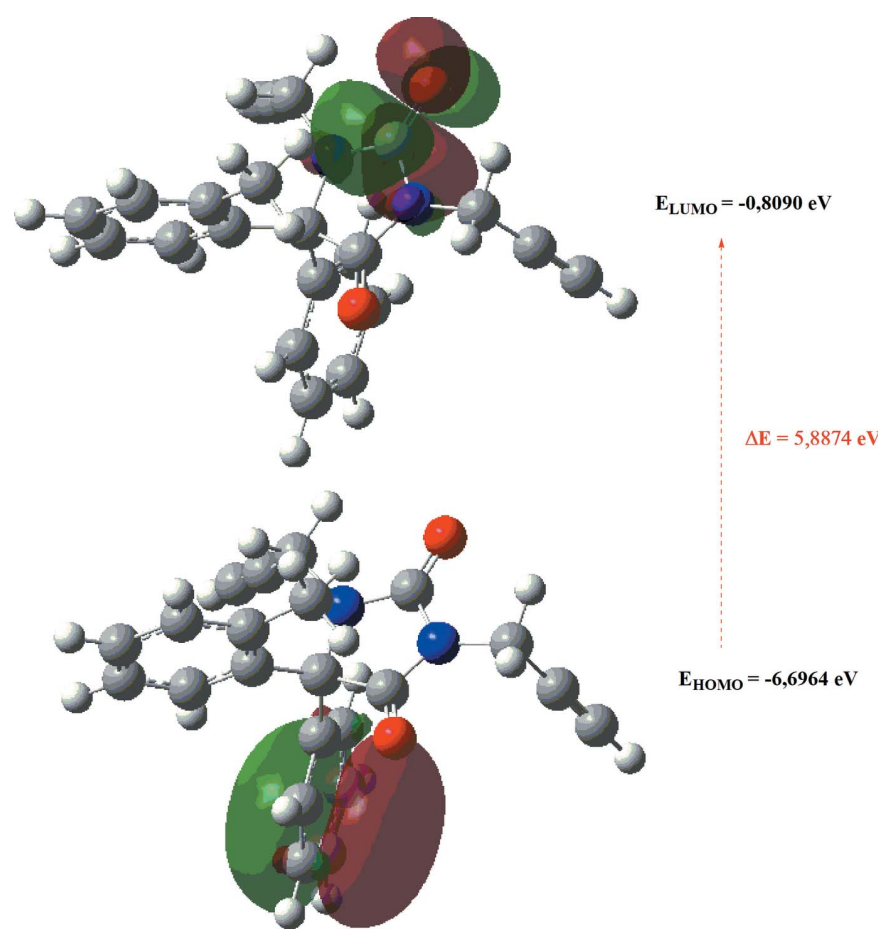

Figure 8

The energy band gap of the title compound.
Table 5

Experimental details.

\begin{tabular}{|c|c|}
\hline \multicolumn{2}{|l|}{ Crystal data } \\
\hline Chemical formula & $\mathrm{C}_{21} \mathrm{H}_{16} \mathrm{~N}_{2} \mathrm{O}_{2}$ \\
\hline$M_{\mathrm{r}}$ & 328.36 \\
\hline Crystal system, space group & Monoclinic, $P 2_{1}$ \\
\hline Temperature $(\mathrm{K})$ & 296 \\
\hline$a, b, c(\AA)$ & $10.144(3), 7.952(2), 10.928(3)$ \\
\hline$\beta\left(^{\circ}\right)$ & $97.104(12)$ \\
\hline$V\left(\AA^{3}\right)$ & $874.8(4)$ \\
\hline$Z$ & 2 \\
\hline Radiation type & Mo $K \alpha$ \\
\hline$\mu\left(\mathrm{mm}^{-1}\right)$ & 0.08 \\
\hline Crystal size $(\mathrm{mm})$ & $0.34 \times 0.17 \times 0.12$ \\
\hline \multicolumn{2}{|l|}{ Data collection } \\
\hline Diffractometer & Bruker APEXII CCD \\
\hline Absorption correction & $\begin{array}{l}\text { Multi-scan (SADABS; Bruker, } \\
\text { 2016) }\end{array}$ \\
\hline$T_{\min }, T_{\max }$ & $0.694,0.746$ \\
\hline $\begin{array}{l}\text { No. of measured, independent and } \\
\text { observed }[I>2 \sigma(I)] \text { reflections }\end{array}$ & $21744,3988,3529$ \\
\hline$R_{\text {int }}$ & 0.037 \\
\hline$(\sin \theta / \lambda)_{\max }\left(\AA^{-1}\right)$ & 0.650 \\
\hline \multicolumn{2}{|l|}{ Refinement } \\
\hline$R\left[F^{2}>2 \sigma\left(F^{2}\right)\right], w R\left(F^{2}\right), S$ & $0.035,0.090,1.03$ \\
\hline No. of reflections & 3988 \\
\hline No. of parameters & 290 \\
\hline No. of restraints & 1 \\
\hline $\mathrm{H}$-atom treatment & All $\mathrm{H}$-atom parameters refined \\
\hline$\Delta \rho_{\max }, \Delta \rho_{\min }\left(\mathrm{e} \AA^{-3}\right)$ & $0.14,-0.16$ \\
\hline Absolute structure & $\begin{array}{l}\text { Flack } x \text { determined using } 1436 \\
\text { quotients }\left[\left(I^{+}\right)-\left(I^{-}\right)\right] /\left[\left(I^{+}\right)+\left(I^{-}\right)\right] \\
\text {(Parsons et al., 2013) }\end{array}$ \\
\hline Absolute structure parameter & $-0.3(4)$ \\
\hline
\end{tabular}

Computer programs: APEX3 and SAINT (Bruker, 2016), SHELXT (Sheldrick, 2015a), SHELXL (Sheldrick, 2015b) and OLEX2 (Dolomanov et al., 2009).

stability of a compound. The electron transition from the HOMO to the LUMO energy level is shown in Fig. 8. The HOMO and LUMO are localized in the plane extending from the whole 5,5-diphenyl-1,3-di(prop-2-yn-1-yl)imidazolidine2,4-dione ring. The energy band gap [ $\left.\Delta E=E_{\mathrm{LUMO}}-E_{\mathrm{HOMO}}\right]$ of the molecule is about $5.8874 \mathrm{eV}$, and the frontier molecular orbital energies, $E_{\text {HOMO }}$ and $E_{\text {LUMO }}$ are -6.6964 and $-0.8090 \mathrm{eV}$, respectively.

\section{Database survey}

A non-alkylated analogue, namely 5,5-diphenylimidazolidine2,4-dione, has been reported (Camerman \& Camerman, 1971), as well as three similar structures, 3- $n$-pentyl-5,5-diphenylimidazolidine-2,4-dione (Guerrab et al., 2017), 3-benzyl-5,5 diphenylimidazolidine-2,4-dione (Guerrab et al., 2018) and 3[2-(4-fluorophenyl)-2-oxoethyl]-5,5 diphenylimidazolidine2,4-dione (Mague et al., 2014).

\section{Synthesis and crystallization}

The appropriate bromide propargil $(2.4 \mathrm{ml}, 20.0 \mathrm{mmol})$ was added to a solution of 5,5 diphenylhydantoin (3.52 g, $10.0 \mathrm{mmol})$ in DMF $(50 \mathrm{ml})$, potassium carbonate $(2.76 \mathrm{~g}$, $20.0 \mathrm{mmol})$ and tetra- $n$-butylammonium bromide $(0.32 \mathrm{~g}$, 
$1.0 \mathrm{mmol}$ ) at room temperature. The reaction was monitored using TLC. After removal of the inorganic salt by filtration, the solution was evaporated under reduced pressure. The residue was separated by chromatography on a column of silica gel with ethyl acetate-hexane ( $v: v$ 3:7) as eluent. The isolated solid was crystallized from ethanol solution to afford colourless crystals (yield: $82 \%$ ).

\section{Refinement}

Crystal data, data collection and structure refinement details are summarized in Table 5. Hydrogen atoms were located in a difference-Fourier map, and refined freely. The Flack absolute structure parameter (Parsons et al., 2013) was refined; expected values are 0 for the correct and +1 for the inverted absolute structure. The refined value is -0.3 (4) (Sheldrick, $2015 b$ ). Since the large e.s.d. means that the assignment is not unambiguous, the absolute structure was not determined reliably.

\section{Funding information}

TH is grateful to the Hacettepe University Scientific Research Project Unit (grant No. 013 D04 602 004).

\section{References}

Amir, M. \& Kumar, S. (2005). Indian J. Chem. 44B, 2532-2537. Badawey, E. A. M. \& El-Ashmawey, I. M. (1998). Eur. J. Med. Chem. 33, 349-361.

Becke, A. D. (1993). J. Chem. Phys. 98, 5648-5652.

Bruker (2016). APEX3, SAINT and SADABS. Bruker AXS, Inc., Madison, Wisconsin, USA.

Camerman, A. \& Camerman, N. (1971). Acta Cryst. B27, 2205-2211.

Das, N., Verma, A., Shrivastava, P. K. \& Shrivastava, S. K. (2008). Indian J. Chem. B47, 1555-1558.

Dolomanov, O. V., Bourhis, L. J., Gildea, R. J., Howard, J. A. K. \& Puschmann, H. (2009). J. Appl. Cryst. 42, 339-341.

Frisch, M. J., et al. (2009). GAUSSIAN09. Gaussian Inc., Wallingford, CT, USA.

Guerrab, W., Akrad, R., Ansar, M., Taoufik, J., Mague, J. T. \& Ramli, Y. (2017). IUCrData, 2, x171693.
Guerrab, W., Akrad, R., Ansar, M., Taoufik, J., Mague, J. T. \& Ramli, Y. (2018). IUCrData, 3, x171832.

Hathwar, V. R., Sist, M., Jørgensen, M. R. V., Mamakhel, A. H., Wang, X., Hoffmann, C. M., Sugimoto, K., Overgaard, J. \& Iversen, B. B. (2015). IUCrJ, 2, 563-574.

Higashi, Y., Jitsuiki, D., Chayama, K. \& Yoshizumi, M. (2006). Recent. Patents Cardiovasc. Drug. Discov. 1, 85-93.

Hirshfeld, H. L. (1977). Theor. Chim. Acta, 44, 129-138.

Jayatilaka, D., Grimwood, D. J., Lee, A., Lemay, A., Russel, A. J., Taylor, C., Wolff, S. K., Cassam-Chenai, P. \& Whitton, A. (2005). TONTO - A System for Computational Chemistry. Available at: http://hirshfeldsurface.net/

Mackenzie, C. F., Spackman, P. R., Jayatilaka, D. \& Spackman, M. A. (2017). IUCrJ, 4, 575-587.

Mague, J. T., Abdel-Aziz, A. A.-M. \& El-Azab, A. S. (2014). Acta Cryst. E70, o226-0227.

McKinnon, J. J., Jayatilaka, D. \& Spackman, M. A. (2007). Chem. Commun. pp. 3814-3816.

Naik, C. G. \& Malik, C. M. (2010). Orient. J. Chem. 26, 113-116.

Parsons, S., Flack, H. D. \& Wagner, T. (2013). Acta Cryst. B69, 249 259.

Pathak, R. B. \& Bahel, S. C. (1980). J. Indian Chem. Soc. 57, 1108 1111.

Pawar, R. A. \& Patil, A. A. (1994). Indian J. Chem. 33B, 156158.

Sahu, S. K., Azam, A. M., Banerjee, M., Choudhary, P., Sutradhar, S., Panda, P. K. \& Misra, P. K. (2007). J. Indian Chem. Soc. 84, 10111015.

Sheldrick, G. M. (2015a). Acta Cryst. A71, 3-8.

Sheldrick, G. M. (2015b). Acta Cryst. C71, 3-8.

Singh, D. \& Singh, D. (1991). J. Indian Chem. Soc. 68, 165-167.

Spackman, M. A. \& Jayatilaka, D. (2009). CrystEngComm, 11, 1932.

Spackman, M. A., McKinnon, J. J. \& Jayatilaka, D. (2008). CrystEngComm, 10, 377-388.

Srivalli, T., Satish, K. \& Suthakaran, R. (2011). Int. J. Innov. Pharm. Res. 2, 172-174.

Turner, M. J., Grabowsky, S., Jayatilaka, D. \& Spackman, M. A. (2014). J. Phys. Chem. Lett. 5, 4249-4255.

Turner, M. J., McKinnon, J. J., Wolff, S. K., Grimwood, D. J., Spackman, P. R., Jayatilaka, D. \& Spackman, M. A. (2017). CrystalExplorer17. The University of Western Australia.

Turner, M. J., Thomas, S. P., Shi, M. W., Jayatilaka, D. \& Spackman, M. A. (2015). Chem. Commun. 51, 3735-3738.

Venkatesan, P., Thamotharan, S., Ilangovan, A., Liang, H. \& Sundius, T. (2016). Spectrochim. Acta Part A, 153, 625-636. 


\section{supporting information}

Acta Cryst. (2019). E75, 951-956 [https://doi.org/10.1107/S2056989019007801]

Crystal structure, Hirshfeld surface analysis and interaction energy and DFT studies of 5,5-diphenyl-1,3-bis(prop-2-yn-1-yl)imidazolidine-2,4-dione

Ismail Ghandour, Abdelouahed Bouayad, Tuncer Hökelek, Amal Haoudi, Frédéric Capet, Catherine Renard and Youssef Kandri Rodi

Computing details

Data collection: APEX3 (Bruker, 2016); cell refinement: SAINT (Bruker, 2016); data reduction: SAINT (Bruker, 2016); program(s) used to solve structure: SHELXT (Sheldrick, 2015a); program(s) used to refine structure: SHELXL (Sheldrick, 2015b); molecular graphics: OLEX2 (Dolomanov et al., 2009); software used to prepare material for publication: OLEX2 (Dolomanov et al., 2009).

5,5-Diphenyl-1,3-bis(prop-2-yn-1-yl)imidazolidine-2,4-dione

Crystal data

$\mathrm{C}_{21} \mathrm{H}_{16} \mathrm{~N}_{2} \mathrm{O}_{2}$

$M_{r}=328.36$

Monoclinic, $P 2$

$a=10.144(3) \AA$

$b=7.952(2) \AA$

$c=10.928(3) \AA$

$\beta=97.104(12)^{\circ}$

$V=874.8(4) \AA^{3}$

$Z=2$

$F(000)=344$

$D_{\mathrm{x}}=1.247 \mathrm{Mg} \mathrm{m}^{-3}$

Mo $K \alpha$ radiation, $\lambda=0.71073 \AA$

Cell parameters from 9652 reflections

$\theta=3.2-27.2^{\circ}$

$\mu=0.08 \mathrm{~mm}^{-1}$

$T=296 \mathrm{~K}$

Prism, colourless

$0.34 \times 0.17 \times 0.12 \mathrm{~mm}$

\section{Data collection}

Bruker APEXII CCD

diffractometer

$\varphi$ and $\omega$ scans

Absorption correction: multi-scan

(SADABS; Bruker, 2016)

$T_{\min }=0.694, T_{\max }=0.746$

21744 measured reflections

3988 independent reflections

3529 reflections with $I>2 \sigma(I)$

$R_{\text {int }}=0.037$

$\theta_{\max }=27.5^{\circ}, \theta_{\min }=1.9^{\circ}$

$h=-13 \rightarrow 13$

$k=-10 \rightarrow 10$

$l=-13 \rightarrow 14$

Refinement

Refinement on $F^{2}$

Least-squares matrix: full

$R\left[F^{2}>2 \sigma\left(F^{2}\right)\right]=0.035$

$w R\left(F^{2}\right)=0.090$

$S=1.03$

3988 reflections

290 parameters

1 restraint

Primary atom site location: dual

Hydrogen site location: difference Fourier map

All $\mathrm{H}$-atom parameters refined

$w=1 /\left[\sigma^{2}\left(F_{\mathrm{o}}^{2}\right)+(0.0457 P)^{2}+0.0829 P\right]$

where $P=\left(F_{\mathrm{o}}^{2}+2 F_{\mathrm{c}}^{2}\right) / 3$

$(\Delta / \sigma)_{\max }<0.001$

$\Delta \rho_{\max }=0.14{\mathrm{e} \AA^{-3}}^{-3}$

$\Delta \rho_{\min }=-0.16 \mathrm{e} \AA^{-3}$ 
Absolute structure: Flack $x$ determined using

1436 quotients $\left[\left(I^{+}\right)-\left(I^{-}\right)\right] /\left[\left(I^{+}\right)+\left(I^{-}\right)\right]$(Parsons et al., 2013)

Absolute structure parameter: $-0.3(4)$

Special details

Geometry. All esds (except the esd in the dihedral angle between two 1.s. planes) are estimated using the full covariance matrix. The cell esds are taken into account individually in the estimation of esds in distances, angles and torsion angles; correlations between esds in cell parameters are only used when they are defined by crystal symmetry. An approximate (isotropic) treatment of cell esds is used for estimating esds involving l.s. planes.

Fractional atomic coordinates and isotropic or equivalent isotropic displacement parameters $\left(\AA^{2}\right)$

\begin{tabular}{|c|c|c|c|c|}
\hline & $x$ & $y$ & $z$ & $U_{\text {iso }} * / U_{\text {eq }}$ \\
\hline $\mathrm{O} 1$ & $0.27390(15)$ & $0.2664(2)$ & $0.19321(15)$ & $0.0502(4)$ \\
\hline $\mathrm{O} 2$ & $-0.01151(15)$ & $0.7093(2)$ & $0.18041(16)$ & $0.0521(4)$ \\
\hline N1 & $0.10965(17)$ & $0.4650(2)$ & $0.16652(16)$ & $0.0421(4)$ \\
\hline N2 & $0.20794(16)$ & $0.6856(2)$ & $0.26052(16)$ & $0.0408(4)$ \\
\hline $\mathrm{C} 1$ & $0.30827(18)$ & 0.5513 & $0.27974(18)$ & $0.0380(4)$ \\
\hline $\mathrm{C} 2$ & $0.2324(2)$ & $0.4054(3)$ & $0.20923(18)$ & $0.0387(4)$ \\
\hline $\mathrm{C} 3$ & 0.09114 (19) & $0.6317(3)$ & $0.20165(18)$ & $0.0390(4)$ \\
\hline $\mathrm{C} 4$ & $0.33794(18)$ & $0.5114(2)$ & 0.41722 (19) & $0.0385(4)$ \\
\hline $\mathrm{C} 5$ & $0.2604(2)$ & $0.3960(3)$ & $0.4718(2)$ & $0.0458(5)$ \\
\hline C6 & $0.2784(3)$ & $0.3712(4)$ & $0.5987(2)$ & $0.0565(6)$ \\
\hline $\mathrm{C} 7$ & $0.3738(3)$ & $0.4604(4)$ & $0.6713(2)$ & $0.0572(6)$ \\
\hline $\mathrm{C} 8$ & $0.4520(2)$ & 0.5750 & $0.6180(2)$ & $0.0526(6)$ \\
\hline C9 & $0.4342(2)$ & $0.6008(3)$ & $0.4921(2)$ & $0.0454(5)$ \\
\hline $\mathrm{C} 10$ & 0.42895 (19) & $0.5861(3)$ & 0.21163 (19) & 0.0395 (4) \\
\hline C11 & $0.5495(2)$ & 0.5070 & $0.2474(2)$ & $0.0441(5)$ \\
\hline $\mathrm{C} 12$ & $0.6546(2)$ & $0.5272(3)$ & $0.1782(2)$ & $0.0543(6)$ \\
\hline $\mathrm{C} 13$ & $0.6410(3)$ & $0.6249(4)$ & $0.0733(2)$ & $0.0606(6)$ \\
\hline $\mathrm{C} 14$ & $0.5225(3)$ & $0.7025(4)$ & $0.0372(2)$ & $0.0622(7)$ \\
\hline $\mathrm{C} 15$ & $0.4163(2)$ & $0.6834(3)$ & $0.1052(2)$ & $0.0538(6)$ \\
\hline $\mathrm{C} 16$ & 0.0113 & $0.3724(4)$ & $0.0851(2)$ & $0.0541(6)$ \\
\hline $\mathrm{C} 17$ & $-0.0433(2)$ & $0.2305(3)$ & 0.1448 & $0.0613(7)$ \\
\hline C18 & $-0.0849(4)$ & $0.1125(5)$ & $0.1895(5)$ & $0.1046(14)$ \\
\hline C19 & $0.2236(3)$ & $0.8536(3)$ & $0.3129(2)$ & $0.0504(5)$ \\
\hline $\mathrm{C} 20$ & $0.1674(3)$ & $0.8738(4)$ & 0.4290 & $0.0701(8)$ \\
\hline $\mathrm{C} 21$ & $0.1218(5)$ & $0.8918(10)$ & $0.5191(5)$ & $0.136(2)$ \\
\hline H5 & $0.189(2)$ & $0.328(3)$ & $0.420(2)$ & $0.051(7)^{*}$ \\
\hline H6 & $0.228(3)$ & $0.296(4)$ & $0.632(3)$ & $0.068(8)^{*}$ \\
\hline H7 & $0.389(3)$ & $0.445(4)$ & $0.763(3)$ & $0.080(10)^{*}$ \\
\hline H8 & $0.522(3)$ & $0.636(4)$ & $0.669(2)$ & $0.059(7)^{*}$ \\
\hline H9 & $0.486(3)$ & $0.677(4)$ & $0.455(3)$ & $0.075(9)^{*}$ \\
\hline H11 & $0.562(2)$ & $0.435(4)$ & $0.323(2)$ & $0.054(7)^{*}$ \\
\hline H12 & $0.736(3)$ & $0.474(4)$ & $0.203(3)$ & $0.069(8)^{*}$ \\
\hline H13 & $0.720(3)$ & $0.641(4)$ & $0.027(3)$ & $0.068(8)^{*}$ \\
\hline H14 & $0.511(3)$ & $0.777(4)$ & $-0.037(3)$ & $0.072(8)^{*}$ \\
\hline H15 & $0.330(3)$ & $0.737(4)$ & $0.076(3)$ & $0.060(7)^{*}$ \\
\hline
\end{tabular}




\begin{tabular}{|c|c|c|c|c|}
\hline H16A & -0.051 & $0.446(4)$ & $0.056(3)$ & $0.060(8)^{*}$ \\
\hline H16B & $0.053(3)$ & $0.332(4)$ & $0.014(3)$ & $0.070(9)^{*}$ \\
\hline H18 & $-0.113(6)$ & $0.010(8)$ & $0.228(6)$ & $0.18(2)^{*}$ \\
\hline H19A & $0.315(3)$ & $0.879(4)$ & $0.328(2)$ & $0.061(7)^{*}$ \\
\hline H19B & $0.182(3)$ & $0.926(4)$ & $0.250(3)$ & $0.067(8)^{*}$ \\
\hline $\mathrm{H} 21$ & $0.087(5)$ & $0.905(8)$ & $0.590(5)$ & $0.16(2)^{*}$ \\
\hline
\end{tabular}

Atomic displacement parameters $\left(\AA^{2}\right)$

\begin{tabular}{|c|c|c|c|c|c|c|}
\hline & $U^{11}$ & $U^{22}$ & $U^{33}$ & $U^{12}$ & $U^{13}$ & $U^{23}$ \\
\hline $\mathrm{O} 1$ & $0.0528(9)$ & $0.0399(8)$ & $0.0585(10)$ & $0.0036(7)$ & $0.0088(7)$ & $-0.0076(7)$ \\
\hline $\mathrm{O} 2$ & $0.0430(8)$ & $0.0499(9)$ & $0.0606(10)$ & $0.0084(7)$ & $-0.0045(7)$ & $0.0041(7)$ \\
\hline N1 & $0.0425(9)$ & $0.0389(9)$ & $0.0426(9)$ & $-0.0019(7)$ & $-0.0033(7)$ & $-0.0008(8)$ \\
\hline $\mathrm{N} 2$ & $0.0373(8)$ & $0.0349(9)$ & $0.0492(10)$ & $0.0009(7)$ & $0.0014(7)$ & $-0.0011(7)$ \\
\hline $\mathrm{C} 1$ & $0.0361(9)$ & $0.0342(9)$ & $0.0432(11)$ & $0.0012(8)$ & $0.0035(8)$ & $0.0012(8)$ \\
\hline $\mathrm{C} 2$ & $0.0414(10)$ & $0.0385(10)$ & $0.0368(10)$ & $-0.0003(8)$ & $0.0070(8)$ & $0.0009(8)$ \\
\hline $\mathrm{C} 3$ & $0.0396(10)$ & $0.0403(11)$ & $0.0365(10)$ & $0.0013(8)$ & $0.0024(8)$ & $0.0058(8)$ \\
\hline $\mathrm{C} 4$ & $0.0349(9)$ & $0.0385(11)$ & $0.0423(11)$ & $0.0052(8)$ & $0.0055(8)$ & $0.0012(8)$ \\
\hline $\mathrm{C} 5$ & $0.0414(11)$ & $0.0468(12)$ & $0.0501(12)$ & $0.0006(9)$ & $0.0094(9)$ & $0.0032(10)$ \\
\hline C6 & $0.0574(13)$ & $0.0592(15)$ & $0.0556(14)$ & $0.0074(12)$ & 0.0183 (11) & $0.0142(12)$ \\
\hline $\mathrm{C} 7$ & $0.0644(15)$ & 0.0677 (16) & $0.0400(12)$ & $0.0230(13)$ & $0.0082(10)$ & 0.0047 (11) \\
\hline $\mathrm{C} 8$ & $0.0531(12)$ & 0.0545 (14) & $0.0476(13)$ & 0.0104 (11) & $-0.0037(10)$ & $-0.0093(11)$ \\
\hline $\mathrm{C} 9$ & $0.0438(11)$ & $0.0440(11)$ & $0.0478(12)$ & $0.0016(9)$ & $0.0035(9)$ & $-0.0013(9)$ \\
\hline $\mathrm{C} 10$ & $0.0386(9)$ & $0.0391(11)$ & $0.0412(10)$ & $-0.0022(8)$ & $0.0060(7)$ & $0.0009(8)$ \\
\hline C11 & $0.0405(10)$ & $0.0450(12)$ & 0.0468 (12) & $0.0014(9)$ & $0.0054(9)$ & $0.0040(10)$ \\
\hline $\mathrm{C} 12$ & $0.0419(11)$ & $0.0616(15)$ & $0.0605(15)$ & $0.0032(11)$ & 0.0105 (10) & $0.0011(12)$ \\
\hline C13 & $0.0519(13)$ & 0.0735 (17) & $0.0601(14)$ & $-0.0040(12)$ & $0.0219(11)$ & 0.0055 (13) \\
\hline C14 & 0.0692 (16) & 0.0698 (17) & 0.0498 (14) & $-0.0003(13)$ & $0.0166(12)$ & 0.0179 (13) \\
\hline C15 & $0.0482(12)$ & $0.0622(15)$ & 0.0507 (13) & $0.0044(11)$ & $0.0053(10)$ & $0.0129(12)$ \\
\hline C16 & $0.0540(13)$ & $0.0525(14)$ & $0.0520(14)$ & $-0.0059(11)$ & $-0.0086(11)$ & $-0.0047(12)$ \\
\hline C17 & $0.0463(12)$ & $0.0490(14)$ & $0.088(2)$ & $-0.0035(10)$ & 0.0067 (12) & $-0.0068(13)$ \\
\hline C18 & $0.081(2)$ & $0.066(2)$ & $0.174(4)$ & $-0.0128(18)$ & $0.043(2)$ & $0.017(2)$ \\
\hline C19 & $0.0479(13)$ & $0.0358(11)$ & $0.0664(15)$ & $0.0013(9)$ & $0.0025(11)$ & $-0.0020(11)$ \\
\hline $\mathrm{C} 20$ & $0.0587(15)$ & 0.0758 (19) & 0.0742 (19) & $0.0032(14)$ & $0.0024(13)$ & $-0.0289(16)$ \\
\hline $\mathrm{C} 21$ & $0.103(3)$ & $0.214(6)$ & $0.094(3)$ & $0.001(4)$ & $0.026(2)$ & -0.069 (4) \\
\hline
\end{tabular}

Geometric parameters $\left(\AA,{ }^{\circ}\right)$

\begin{tabular}{llll}
\hline $\mathrm{O} 1-\mathrm{C} 2$ & $1.203(3)$ & $\mathrm{C} 10-\mathrm{C} 11$ & $1.388(3)$ \\
$\mathrm{O} 2-\mathrm{C} 3$ & $1.208(2)$ & $\mathrm{C} 10-\mathrm{C} 15$ & $1.390(3)$ \\
$\mathrm{N} 1-\mathrm{C} 2$ & $1.360(3)$ & $\mathrm{C} 11-\mathrm{C} 12$ & $1.391(3)$ \\
$\mathrm{N} 1-\mathrm{C} 3$ & $\mathrm{C} 11-\mathrm{H} 11$ & $1.00(3)$ \\
$\mathrm{N} 1-\mathrm{C} 16$ & $1.399(3)$ & $\mathrm{C} 12-\mathrm{C} 13$ & $1.377(4)$ \\
$\mathrm{N} 2-\mathrm{C} 1$ & $1.453(3)$ & $\mathrm{C} 12-\mathrm{H} 12$ & $0.94(3)$ \\
$\mathrm{N} 2-\mathrm{C} 3$ & $1.472(3)$ & $\mathrm{C} 13-\mathrm{C} 14$ & $1.366(4)$ \\
$\mathrm{N} 2-\mathrm{C} 19$ & $1.346(3)$ & $\mathrm{C} 13-\mathrm{H} 13$ & $1.01(3)$ \\
$\mathrm{C} 1-\mathrm{C} 10$ & $1.454(3)$ & $\mathrm{C} 14-\mathrm{H} 14$ & $1.00(3)$ \\
$\mathrm{C} 2-\mathrm{C} 1$ & $1.534(3)$ & $\mathrm{C} 15-\mathrm{C} 14$ & $1.390(4)$
\end{tabular}




\begin{tabular}{|c|c|c|c|}
\hline $\mathrm{C} 4-\mathrm{C} 1$ & $1.529(3)$ & $\mathrm{C} 15-\mathrm{H} 15$ & $0.99(3)$ \\
\hline $\mathrm{C} 4-\mathrm{C} 5$ & $1.390(3)$ & $\mathrm{C} 16-\mathrm{H} 16 \mathrm{~A}$ & $0.89(3)$ \\
\hline $\mathrm{C} 4-\mathrm{C} 9$ & $1.390(3)$ & $\mathrm{C} 16-\mathrm{H} 16 \mathrm{~B}$ & $0.98(3)$ \\
\hline $\mathrm{C} 5-\mathrm{C} 6$ & $1.389(3)$ & $\mathrm{C} 17-\mathrm{C} 16$ & $1.447(4)$ \\
\hline $\mathrm{C} 5-\mathrm{H} 5$ & $1.02(3)$ & $\mathrm{C} 17-\mathrm{C} 18$ & $1.162(5)$ \\
\hline $\mathrm{C} 6-\mathrm{C} 7$ & $1.370(4)$ & C18-H18 & $0.97(6)$ \\
\hline $\mathrm{C} 6-\mathrm{H} 6$ & $0.90(3)$ & $\mathrm{C} 19-\mathrm{C} 20$ & $1.462(4)$ \\
\hline $\mathrm{C} 7-\mathrm{H} 7$ & $1.01(3)$ & C19-H19A & $0.94(3)$ \\
\hline $\mathrm{C} 8-\mathrm{C} 7$ & $1.384(4)$ & C19-H19B & $0.95(3)$ \\
\hline $\mathrm{C} 8-\mathrm{H} 8$ & $0.98(3)$ & $\mathrm{C} 20-\mathrm{C} 21$ & $1.148(5)$ \\
\hline $\mathrm{C} 9-\mathrm{C} 8$ & $1.380(3)$ & $\mathrm{C} 21-\mathrm{H} 21$ & $0.90(5)$ \\
\hline C9-H9 & $0.93(3)$ & & \\
\hline $\mathrm{O} 1 \cdots \mathrm{H} 16 \mathrm{~B}$ & $2.84(2)$ & $\mathrm{C} 20 \cdots \mathrm{C} 4$ & $3.372(3)$ \\
\hline $\mathrm{O} 1 \cdots \mathrm{H} 13^{\mathrm{i}}$ & $2.61(2)$ & $\mathrm{C} 20 \cdots \mathrm{C} 9$ & $3.472(3)$ \\
\hline $\mathrm{O} 1 \cdots \mathrm{H} 5$ & 2.767 (18) & $\mathrm{C} 2 \cdots \mathrm{H} 5$ & $2.476(18)$ \\
\hline $\mathrm{O} 1 \cdots \mathrm{H} 8^{\mathrm{ii}}$ & $2.62(2)$ & $\mathrm{C} 4 \cdots \mathrm{H} 11$ & $2.679(18)$ \\
\hline $\mathrm{O} 2 \cdots \mathrm{H} 18^{\mathrm{iii}}$ & $2.68(5)$ & $\mathrm{C} 6 \cdots \mathrm{H} 9^{\mathrm{ii}}$ & $2.97(2)$ \\
\hline $\mathrm{O} 2 \cdots \mathrm{H} 19 \mathrm{~B}$ & $2.65(2)$ & $\mathrm{C} 6 \cdots \mathrm{H} 18^{\mathrm{v}}$ & $2.90(4)$ \\
\hline $\mathrm{O} 2 \cdots \mathrm{H} 16 \mathrm{~A}$ & $2.50(2)$ & $\mathrm{C} 8 \cdots \mathrm{H} 11^{\mathrm{vi}}$ & $2.94(2)$ \\
\hline $\mathrm{O} 2 \cdots \mathrm{H} 16 \mathrm{~B}^{\mathrm{iv}}$ & $2.33(2)$ & C8‥H19A ${ }^{\mathrm{ii}}$ & $2.83(2)$ \\
\hline $\mathrm{N} 2 \cdots \mathrm{H} 15$ & $2.53(2)$ & $\mathrm{C} 9 \cdots \mathrm{H} 11$ & $2.73(2)$ \\
\hline $\mathrm{C} 4 \cdots \mathrm{C} 20$ & $3.372(3)$ & $\mathrm{C} 10 \cdots \mathrm{H} 9$ & $2.75(2)$ \\
\hline C9 $\cdots$ C 19 & $3.378(3)$ & C10 $\cdots$ H19A & $2.96(2)$ \\
\hline C9 $\cdots \mathrm{C} 11$ & $3.138(3)$ & $\mathrm{C} 11 \cdots \mathrm{H} 14^{\mathrm{i}}$ & $2.94(2)$ \\
\hline $\mathrm{C} 9 \cdots \mathrm{C} 20$ & $3.472(3)$ & $\mathrm{C} 11 \cdots \mathrm{H} 9$ & $2.79(2)$ \\
\hline $\mathrm{C} 11 \cdots \mathrm{C} 9$ & $3.138(3)$ & $\mathrm{C} 12 \cdots \mathrm{H} 14^{\mathrm{i}}$ & $2.91(2)$ \\
\hline $\mathrm{C} 15 \cdots \mathrm{C} 19$ & $3.450(3)$ & $\mathrm{C} 14 \cdots \mathrm{H} 7^{\mathrm{vi}}$ & $2.97(2)$ \\
\hline $\mathrm{C} 19 \cdots \mathrm{C} 15$ & $3.450(3)$ & $\mathrm{H} 8 \cdots \mathrm{H} 11^{\mathrm{vi}}$ & $2.53(3)$ \\
\hline 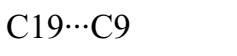 & $3.378(3)$ & H9 $\cdots$ H11 & $2.58(3)$ \\
\hline $\mathrm{C} 2-\mathrm{N} 1-\mathrm{C} 3$ & $112.60(17)$ & $\mathrm{C} 8-\mathrm{C} 9-\mathrm{H} 9$ & $121.2(19)$ \\
\hline $\mathrm{C} 2-\mathrm{N} 1-\mathrm{C} 16$ & $124.3(2)$ & $\mathrm{C} 11-\mathrm{C} 10-\mathrm{C} 1$ & $120.65(18)$ \\
\hline $\mathrm{C} 3-\mathrm{N} 1-\mathrm{C} 16$ & $122.9(2)$ & $\mathrm{C} 11-\mathrm{C} 10-\mathrm{C} 15$ & $118.4(2)$ \\
\hline $\mathrm{C} 3-\mathrm{N} 2-\mathrm{C} 1$ & $112.90(16)$ & $\mathrm{C} 15-\mathrm{C} 10-\mathrm{C} 1$ & $120.64(18)$ \\
\hline $\mathrm{C} 3-\mathrm{N} 2-\mathrm{C} 19$ & $121.81(18)$ & $\mathrm{C} 10-\mathrm{C} 11-\mathrm{C} 12$ & $120.2(2)$ \\
\hline $\mathrm{C} 19-\mathrm{N} 2-\mathrm{C} 1$ & $124.78(17)$ & $\mathrm{C} 10-\mathrm{C} 11-\mathrm{H} 11$ & $120.6(14)$ \\
\hline $\mathrm{N} 2-\mathrm{C} 1-\mathrm{C} 2$ & $100.41(15)$ & $\mathrm{C} 12-\mathrm{C} 11-\mathrm{H} 11$ & $119.3(14)$ \\
\hline $\mathrm{N} 2-\mathrm{C} 1-\mathrm{C} 4$ & $109.84(16)$ & $\mathrm{C} 11-\mathrm{C} 12-\mathrm{H} 12$ & $119.8(18)$ \\
\hline $\mathrm{N} 2-\mathrm{C} 1-\mathrm{C} 10$ & $112.27(16)$ & $\mathrm{C} 13-\mathrm{C} 12-\mathrm{C} 11$ & $120.9(2)$ \\
\hline $\mathrm{C} 4-\mathrm{C} 1-\mathrm{C} 2$ & $111.07(16)$ & $\mathrm{C} 13-\mathrm{C} 12-\mathrm{H} 12$ & $119.3(18)$ \\
\hline $\mathrm{C} 4-\mathrm{C} 1-\mathrm{C} 10$ & $116.25(15)$ & $\mathrm{C} 12-\mathrm{C} 13-\mathrm{H} 13$ & $119.5(17)$ \\
\hline $\mathrm{C} 10-\mathrm{C} 1-\mathrm{C} 2$ & $105.76(16)$ & $\mathrm{C} 14-\mathrm{C} 13-\mathrm{C} 12$ & $119.3(2)$ \\
\hline $\mathrm{O} 1-\mathrm{C} 2-\mathrm{N} 1$ & $126.3(2)$ & $\mathrm{C} 14-\mathrm{C} 13-\mathrm{H} 13$ & $121.2(17)$ \\
\hline $\mathrm{O} 1-\mathrm{C} 2-\mathrm{C} 1$ & $126.93(19)$ & $\mathrm{C} 13-\mathrm{C} 14-\mathrm{C} 15$ & $120.6(2)$ \\
\hline $\mathrm{N} 1-\mathrm{C} 2-\mathrm{C} 1$ & $106.74(16)$ & $\mathrm{C} 13-\mathrm{C} 14-\mathrm{H} 14$ & $121.1(17)$ \\
\hline $\mathrm{O} 2-\mathrm{C} 3-\mathrm{N} 1$ & $125.0(2)$ & $\mathrm{C} 15-\mathrm{C} 14-\mathrm{H} 14$ & $118.2(17)$ \\
\hline $\mathrm{O} 2-\mathrm{C} 3-\mathrm{N} 2$ & $128.0(2)$ & $\mathrm{C} 10-\mathrm{C} 15-\mathrm{C} 14$ & $120.7(2)$ \\
\hline
\end{tabular}




\begin{tabular}{|c|c|c|c|}
\hline $\mathrm{N} 2-\mathrm{C} 3-\mathrm{N} 1$ & $107.02(17)$ & $\mathrm{C} 10-\mathrm{C} 15-\mathrm{H} 15$ & $119.9(16)$ \\
\hline $\mathrm{C} 5-\mathrm{C} 4-\mathrm{C} 1$ & $120.41(18)$ & $\mathrm{C} 14-\mathrm{C} 15-\mathrm{H} 15$ & $119.3(16)$ \\
\hline $\mathrm{C} 9-\mathrm{C} 4-\mathrm{C} 1$ & $120.74(18)$ & $\mathrm{N} 1-\mathrm{C} 16-\mathrm{H} 16 \mathrm{~A}$ & $107.0(19)$ \\
\hline $\mathrm{C} 9-\mathrm{C} 4-\mathrm{C} 5$ & $118.6(2)$ & $\mathrm{N} 1-\mathrm{C} 16-\mathrm{H} 16 \mathrm{~B}$ & $108.8(17)$ \\
\hline $\mathrm{C} 4-\mathrm{C} 5-\mathrm{H} 5$ & $121.0(14)$ & $\mathrm{C} 17-\mathrm{C} 16-\mathrm{N} 1$ & $113.0(2)$ \\
\hline $\mathrm{C} 6-\mathrm{C} 5-\mathrm{C} 4$ & $120.7(2)$ & $\mathrm{C} 17-\mathrm{C} 16-\mathrm{H} 16 \mathrm{~A}$ & $112.0(18)$ \\
\hline $\mathrm{C} 6-\mathrm{C} 5-\mathrm{H} 5$ & $118.4(14)$ & $\mathrm{C} 17-\mathrm{C} 16-\mathrm{H} 16 \mathrm{~B}$ & $108.8(18)$ \\
\hline $\mathrm{C} 5-\mathrm{C} 6-\mathrm{H} 6$ & $119(2)$ & $\mathrm{H} 16 \mathrm{~A}-\mathrm{C} 16-\mathrm{H} 16 \mathrm{~B}$ & $107(2)$ \\
\hline $\mathrm{C} 7-\mathrm{C} 6-\mathrm{C} 5$ & $120.0(2)$ & $\mathrm{C} 18-\mathrm{C} 17-\mathrm{C} 16$ & $177.3(4)$ \\
\hline $\mathrm{C} 7-\mathrm{C} 6-\mathrm{H} 6$ & $120.8(19)$ & $\mathrm{C} 17-\mathrm{C} 18-\mathrm{H} 18$ & $176(3)$ \\
\hline $\mathrm{C} 6-\mathrm{C} 7-\mathrm{C} 8$ & $119.8(2)$ & $\mathrm{N} 2-\mathrm{C} 19-\mathrm{C} 20$ & $114.0(2)$ \\
\hline $\mathrm{C} 6-\mathrm{C} 7-\mathrm{H} 7$ & $121.8(18)$ & $\mathrm{N} 2-\mathrm{C} 19-\mathrm{H} 19 \mathrm{~A}$ & $108.9(18)$ \\
\hline $\mathrm{C} 8-\mathrm{C} 7-\mathrm{H} 7$ & $118.3(18)$ & $\mathrm{N} 2-\mathrm{C} 19-\mathrm{H} 19 \mathrm{~B}$ & $104.8(18)$ \\
\hline $\mathrm{C} 7-\mathrm{C} 8-\mathrm{H} 8$ & $120.2(16)$ & $\mathrm{C} 20-\mathrm{C} 19-\mathrm{H} 19 \mathrm{~A}$ & $107.8(16)$ \\
\hline $\mathrm{C} 9-\mathrm{C} 8-\mathrm{C} 7$ & $120.4(2)$ & $\mathrm{C} 20-\mathrm{C} 19-\mathrm{H} 19 \mathrm{~B}$ & $112.0(17)$ \\
\hline $\mathrm{C} 9-\mathrm{C} 8-\mathrm{H} 8$ & $119.3(16)$ & H19A-C19-H19B & $109(2)$ \\
\hline $\mathrm{C} 4-\mathrm{C} 9-\mathrm{H} 9$ & $118.4(19)$ & $\mathrm{C} 21-\mathrm{C} 20-\mathrm{C} 19$ & $178.8(5)$ \\
\hline $\mathrm{C} 8-\mathrm{C} 9-\mathrm{C} 4$ & $120.4(2)$ & $\mathrm{C} 20-\mathrm{C} 21-\mathrm{H} 21$ & $179(4)$ \\
\hline $\mathrm{C} 3-\mathrm{N} 2-\mathrm{C} 1-\mathrm{C} 4$ & $-112.10(13)$ & $\mathrm{C} 2-\mathrm{N} 1-\mathrm{C} 3-\mathrm{N} 2$ & $4.70(16)$ \\
\hline $\mathrm{C} 19-\mathrm{N} 2-\mathrm{C} 1-\mathrm{C} 4$ & $59.82(18)$ & $\mathrm{C} 16-\mathrm{N} 1-\mathrm{C} 3-\mathrm{N} 2$ & $-170.68(14)$ \\
\hline $\mathrm{C} 3-\mathrm{N} 2-\mathrm{C} 1-\mathrm{C} 10$ & $116.91(13)$ & $\mathrm{C} 9-\mathrm{C} 4-\mathrm{C} 5-\mathrm{C} 6$ & $0.3(2)$ \\
\hline $\mathrm{C} 19-\mathrm{N} 2-\mathrm{C} 1-\mathrm{C} 10$ & $-71.17(19)$ & $\mathrm{C} 1-\mathrm{C} 4-\mathrm{C} 5-\mathrm{C} 6$ & $-173.66(14)$ \\
\hline $\mathrm{C} 3-\mathrm{N} 2-\mathrm{C} 1-\mathrm{C} 2$ & $4.97(15)$ & $\mathrm{C} 4-\mathrm{C} 5-\mathrm{C} 6-\mathrm{C} 7$ & $-0.3(3)$ \\
\hline $\mathrm{C} 19-\mathrm{N} 2-\mathrm{C} 1-\mathrm{C} 2$ & $176.88(13)$ & $\mathrm{C} 5-\mathrm{C} 6-\mathrm{C} 7-\mathrm{C} 8$ & $0.0(3)$ \\
\hline $\mathrm{C} 9-\mathrm{C} 4-\mathrm{C} 1-\mathrm{N} 2$ & $-87.33(15)$ & $\mathrm{C} 9-\mathrm{C} 8-\mathrm{C} 7-\mathrm{C} 6$ & $0.3(3)$ \\
\hline $\mathrm{C} 5-\mathrm{C} 4-\mathrm{C} 1-\mathrm{N} 2$ & $86.52(16)$ & $\mathrm{C} 4-\mathrm{C} 9-\mathrm{C} 8-\mathrm{C} 7$ & $-0.3(3)$ \\
\hline $\mathrm{C} 9-\mathrm{C} 4-\mathrm{C} 1-\mathrm{C} 10$ & $41.52(19)$ & $\mathrm{C} 5-\mathrm{C} 4-\mathrm{C} 9-\mathrm{C} 8$ & $0.0(2)$ \\
\hline $\mathrm{C} 5-\mathrm{C} 4-\mathrm{C} 1-\mathrm{C} 10$ & $-144.63(14)$ & $\mathrm{C} 1-\mathrm{C} 4-\mathrm{C} 9-\mathrm{C} 8$ & $173.96(14)$ \\
\hline $\mathrm{C} 9-\mathrm{C} 4-\mathrm{C} 1-\mathrm{C} 2$ & $162.49(13)$ & $\mathrm{N} 2-\mathrm{C} 1-\mathrm{C} 10-\mathrm{C} 11$ & $159.40(13)$ \\
\hline $\mathrm{C} 5-\mathrm{C} 4-\mathrm{C} 1-\mathrm{C} 2$ & $-23.66(18)$ & $\mathrm{C} 4-\mathrm{C} 1-\mathrm{C} 10-\mathrm{C} 11$ & $31.74(19)$ \\
\hline $\mathrm{O} 1-\mathrm{C} 2-\mathrm{C} 1-\mathrm{N} 2$ & $177.04(14)$ & $\mathrm{C} 2-\mathrm{C} 1-\mathrm{C} 10-\mathrm{C} 11$ & $-92.03(15)$ \\
\hline $\mathrm{N} 1-\mathrm{C} 2-\mathrm{C} 1-\mathrm{N} 2$ & $-1.91(14)$ & $\mathrm{N} 2-\mathrm{C} 1-\mathrm{C} 10-\mathrm{C} 15$ & $-27.33(19)$ \\
\hline $\mathrm{O} 1-\mathrm{C} 2-\mathrm{C} 1-\mathrm{C} 4$ & $-66.81(19)$ & $\mathrm{C} 4-\mathrm{C} 1-\mathrm{C} 10-\mathrm{C} 15$ & $-154.99(14)$ \\
\hline $\mathrm{N} 1-\mathrm{C} 2-\mathrm{C} 1-\mathrm{C} 4$ & $114.23(13)$ & $\mathrm{C} 2-\mathrm{C} 1-\mathrm{C} 10-\mathrm{C} 15$ & $81.25(17)$ \\
\hline $\mathrm{O} 1-\mathrm{C} 2-\mathrm{C} 1-\mathrm{C} 10$ & $60.15(19)$ & $\mathrm{C} 15-\mathrm{C} 10-\mathrm{C} 11-\mathrm{C} 12$ & $0.6(2)$ \\
\hline $\mathrm{N} 1-\mathrm{C} 2-\mathrm{C} 1-\mathrm{C} 10$ & $-118.80(12)$ & $\mathrm{C} 1-\mathrm{C} 10-\mathrm{C} 11-\mathrm{C} 12$ & $174.00(15)$ \\
\hline $\mathrm{C} 3-\mathrm{N} 1-\mathrm{C} 2-\mathrm{O} 1$ & $179.51(14)$ & $\mathrm{C} 10-\mathrm{C} 11-\mathrm{C} 12-\mathrm{C} 13$ & $-0.2(3)$ \\
\hline $\mathrm{C} 16-\mathrm{N} 1-\mathrm{C} 2-\mathrm{O} 1$ & $-5.2(2)$ & $\mathrm{C} 11-\mathrm{C} 12-\mathrm{C} 13-\mathrm{C} 14$ & $-0.1(3)$ \\
\hline $\mathrm{C} 3-\mathrm{N} 1-\mathrm{C} 2-\mathrm{C} 1$ & $-1.52(16)$ & $\mathrm{C} 12-\mathrm{C} 13-\mathrm{C} 14-\mathrm{C} 15$ & $0.0(3)$ \\
\hline $\mathrm{C} 16-\mathrm{N} 1-\mathrm{C} 2-\mathrm{C} 1$ & $173.78(14)$ & $\mathrm{C} 10-\mathrm{C} 15-\mathrm{C} 14-\mathrm{C} 13$ & $0.4(3)$ \\
\hline $\mathrm{C} 19-\mathrm{N} 2-\mathrm{C} 3-\mathrm{O} 2$ & $2.4(2)$ & $\mathrm{C} 11-\mathrm{C} 10-\mathrm{C} 15-\mathrm{C} 14$ & $-0.7(3)$ \\
\hline $\mathrm{C} 1-\mathrm{N} 2-\mathrm{C} 3-\mathrm{O} 2$ & $174.63(14)$ & $\mathrm{C} 1-\mathrm{C} 10-\mathrm{C} 15-\mathrm{C} 14$ & $-174.13(17)$ \\
\hline $\mathrm{C} 19-\mathrm{N} 2-\mathrm{C} 3-\mathrm{N} 1$ & $-178.28(14)$ & $\mathrm{C} 2-\mathrm{N} 1-\mathrm{C} 16-\mathrm{C} 17$ & $69.8(2)$ \\
\hline $\mathrm{C} 1-\mathrm{N} 2-\mathrm{C} 3-\mathrm{N} 1$ & $-6.09(16)$ & $\mathrm{C} 3-\mathrm{N} 1-\mathrm{C} 16-\mathrm{C} 17$ & $-115.34(18)$ \\
\hline
\end{tabular}




\begin{tabular}{llll}
$\mathrm{C} 2-\mathrm{N} 1-\mathrm{C} 3-\mathrm{O} 2$ & $-175.99(14)$ & $\mathrm{C} 3-\mathrm{N} 2-\mathrm{C} 19-\mathrm{C} 20$ & $76.6(2)$ \\
$\mathrm{C} 16-\mathrm{N} 1-\mathrm{C} 3-\mathrm{O} 2$ & $8.6(2)$ & $\mathrm{C} 1-\mathrm{N} 2-\mathrm{C} 19-\mathrm{C} 20$ & $-94.61(19)$ \\
\hline
\end{tabular}

Symmetry codes: (i) $-x+1, y-1 / 2,-z$; (ii) $-x+1, y-1 / 2,-z+1$; (iii) $x, y+1, z$; (iv) $-x, y+1 / 2,-z$; (v) $-x, y+1 / 2,-z+1$; (vi) $-x+1, y+1 / 2,-z+1$.

Hydrogen-bond geometry $\left(A,{ }^{\circ}\right)$

$C g 1$ and $C g 2$ are the centroids of the $\mathrm{C} 4-\mathrm{C} 9$ and $\mathrm{C} 10-\mathrm{C} 15$ rings, respectively.

\begin{tabular}{lllll}
\hline$D-\mathrm{H} \cdots A$ & $D-\mathrm{H}$ & $\mathrm{H} \cdots A$ & $D \cdots A$ & $D-\mathrm{H} \cdots A$ \\
\hline $\mathrm{C} 16-\mathrm{H} 16 B \cdots \mathrm{O} 2^{\text {vii }}$ & $0.98(3)$ & $2.33(3)$ & $3.178(3)$ & $144(2)$ \\
$\mathrm{C} 9-\mathrm{H} 9 \cdots C g 1^{\text {vi }}$ & $0.93(3)$ & $2.93(2)$ & $3.778(2)$ & $152.7(17)$ \\
$\mathrm{C} 14-\mathrm{H} 14 \cdots C g 2^{\text {viii }}$ & $1.00(3)$ & $2.87(2)$ & $3.762(3)$ & $149.6(17)$ \\
\hline
\end{tabular}

Symmetry codes: (vi) $-x+1, y+1 / 2,-z+1$; (vii) $-x, y-1 / 2,-z$; (viii) $-x+1, y+1 / 2,-z$. 